\title{
Newcomers on the medical market, dokter djawa 1850-1875
}

In 1847 the head of the Medical Service, W. Bosch, advised the government to train natives as doctors to alleviate the misery of the epidemic in Central Java. He wanted to improve the medical assistance for the population by doing this. The graduates, called dokter djawa, were intended to replace the indigenous healers, the dukun.

MOTIVES FOR THE SCHOOL

In his letter of October 1847 to Governor-General J.J. Rochussen in which he formally submitted the proposal to train natives to be doctors, Bosch used a range of arguments to support it. First of all, he pointed out that the medical knowledge of the Javanese was limited and that the most enlightened natives therefore had no faith in the dukun; they preferred consulting European physicians if there was one nearby. In addition, it was apparent during the latest epidemic in Central Java that the dukun could do little, and the average natives had gratefully taken advantage of European medicines and treatment. Bosch felt that European medical help should not remain limited to special circumstances. He proposed training suitable native youths in the military hospitals to become doctors. This would benefit both the population, who would receive better help, and the government, which could count on population growth and thus on an increase in production in the Cultivation System, and thus a rise in income. He also envisaged a role in the near future for the graduates in combating syphilis. Bosch thought this would meet the wish expressed by many residents who wanted to train natives to do this, as the European physicians were overwhelmed by this 'devastating disease' on their own. Thus, not just for humanitarian reasons but also 
for national interests, Bosch hoped that the governor-general would approve his proposal. It would not cost the country much, and some of the expense of the training would be reimbursed by the expected increase in population. ${ }^{1}$

Improved medical assistance for natives was the reason GovernorGeneral Rochussen decided to support Bosch's initiative. Western assistance - 'which we currently consider the epitome of perfection in this science' - would remain wishful thinking for the natives for a long time to come, given the limited financial means and the many needs in the colony and in the homeland. ${ }^{2}$ Both Bosch and Rochussen wanted to improve the medical assistance for the population and felt that what the dukun provided was inadequate, but they did not come to the conclusion of training the dukun. They wanted to introduce a new group of caregivers to the medical market: natives but ones with Western medical knowledge. They must have realised that replacing the dukun would only be partially successful as long as the population was ill-disposed towards Western medicine and the government refused to force it on them.

\section{DECISION-MAKING}

Bosch's proposal was submitted for review according to the standard procedure to the commander of the Indies Army, lieutenant-general F.D. Cochius, and the Council of the Indies. Cochius considered the greatest drawback of teaching in the proposed school to be the impossibility of increasing the duties for the health officers concerned, as it involved a civilian task and not a military one. In addition, not all officers spoke Malay or Javanese. ${ }^{3}$ Rochussen felt that Cochius's concerns were not insurmountable. In any case, his objection that the health officers could not be given a civilian task did not make sense as they were formally responsible for the medical welfare of citizens. The Council of the Indies

\footnotetext{
1 Letter from Bosch to GG 11-10-1847 no. 134, in: NA, Koloniën, 1814-49, 2.10.01, inv. no. 1849, Vb. 7-4-1848 N 2/205.

$2 \quad$ Letter from GG 26-12-1847 no. 722/2, in: NA, Koloniën, 1814-49, 2.10.01, inv. no. 1849, Vb. 7-4-1848 N 2/205. At that time natives were already being trained in the larger hospitals, but apparently Bosch and Rochussen wanted to impose a more structural approach, AV 1849 residency of Rembang, Archief Schoute Rembang.

Letter from GG 29-11-1847 no. 10, in: NA, Koloniën, 1814-49, 2.10.01, inv. no. 1849, Vb. 7-41848 N 2/205.
} 
approved the proposal. ${ }^{4}$ Already in December 1847, just two months after submitting the proposal, the governor-general forwarded it to the minister of colonies, J.C. Baud, who sent it to the king. ${ }^{5}$ This all took place before the constitutional reform of 1848; the king thus still had complete control over the colonies. Baud knew that a decision had just been made to stop all new civilian expenses in Netherlands Indies, ${ }^{6}$ but he wrote, 'It seems to me that this proposal should form an exception to the rule specified in the beginning of this letter as it is in the interests of the population, and does not represent a great financial burden'. 7 The king agreed with his minister and issued a Royal Decree. ${ }^{8}$

The Colonial Report for 1849 reveals the administration's motives for establishing a medical school. After describing the limited knowledge and arbitrary methods of the dukun, there followed a list of possible problems arising if European physicians would help the population: the native would harbour prejudices against Western medicine, would only pay a tiny fee for it and probably would not follow the physician's prescriptions closely. A large number of European physicians would have to be sent to the interior where they would not find enough private patients to set up independent practices on the side. They would thus have to be paid salaries by the government in compensation ( $K V$ 1849:94). This report implies that the administration wanted to replace the dukun with Western physicians. It was aware of the population's resistance, but hoped that the native doctors would encounter this less than European physicians who were also too expensive. The text is ambiguous about whether the government intended to pay the native doctors - and then a much lower salary than the European physicians - or whether they would have to survive on small payments from the population. Disappointment was a real risk for European physicians because the death of a patient who had

\footnotetext{
4 Letter from GG 26-12-1847 no. 722/2, in: NA, Koloniën, 1814-49, 2.10.01, inv. no. 1849, Vb. 7-4-1848 N 2/205. Unfortunately, the text of the Council of the Indies recommendation could not be found for this book.

Resolution 26-12-1847, Archief Schoute Batavia .

Cabinet's resolution 13-3-1848, in: NA, Koloniën, 1814-49, 2.10.01, inv. no. 1845, Vb. 22-3-1848 no. 26 .

Letter of acting Minister of the Navy and Colonies, J.C. Rijk to the king 7-4-1848 no. 2/205, in: NA, Koloniën, 1814-49, 2.10.01, inv. no. 1845, Vb. 22-3-1848 no. 26.

$8 \quad$ KB 23-3-1848 no. 104, in: NA, Koloniën, 1814-49, 2.10.01, inv. no. 1849, Vb. 7-4-1848 N 2/205. According to Kumar 2005:81, the medical training in British India served as a model. No indications for this were found in the sources. It is well-known that major-general F.B. Freiherr von Gagern did visit British India on his journey back to the Netherlands from the Indies and sent information about the medical training from there to The Hague, Von Gagern 1866:326-34.
} 
ignored their prescriptions would be blamed on their incompetence and would result in patients' distrust of Western medicine and its practitioners. This was apparent from the memoirs of A. Pruys van der Hoeven (1894:61), who as a controleur in the interior of Sumatra occasionally supplied medical services:

It is thus very difficult, when acting as a physician, to uphold the prestige of medicine. As controleur in Kajoe Tanam, Sumatra's West Coast, I personally experienced during a cholera epidemic that I distributed to the village heads two bottles given to me by the Medical Service, one with a white label for internal use, the other with a blue label for external use, and found out that in the kampong, to avoid confusion, the contents of both bottles were mixed and then alternately drunk and rubbed in by patients, until they died.

\section{ASSISTANT DOCTORS OR VACGINATORS?}

The Royal Decree of 1848 turned the proposal into reality, but it was not clear what the training programme would produce. It stated that funds would be granted to the governor-general 'to train native youths in the primary requirements for the exercise of medicine'. 9 The official name of the training programme was School ter opleiding van Inlandsche Geneeskundigen (School to train native doctors) (Lauw 1987:40). Bosch himself (1853:468) created confusion in the first place by stating in the application that the graduates could be employed as practising doctors and as vaccinators. Afraid that the graduates would not earn a decent living from their practice, he proposed employing them as vaccinators in preference to other candidates. Bosch referred to his earlier proposal of March 1846 on improvement of the vaccination regulations and the vaccination personnel. ${ }^{10}$ Thus far, the government had not yet replied. From pragmatic considerations - he 'did not mean to go further than what he felt was feasible' (Bleeker 1877:33) - Bosch linked the two proposals

$9 \quad$ KB 23-11-1848 no. 104 cited in $K V$ 1847-48:14; in the same $K V$ on the same page, mention is made of additional funds to pay the hospitals to train native vaccinators. In this $K V$ two different training courses seem to be involved.

1o Letter from Bosch to GG 11-10-1847 no. 134, in: NA, Koloniën, 1814-49, 2.10.01, inv. no. 1849, Vb. 7-4-1848 N 2/20; it concerns the proposal of 25-3-1846 no. 538. 
together. He thought perhaps to kill two birds with one stone: the graduates had the prospective of a job, and the government would approve his proposal sooner to train young men to be doctors if they could also act as vaccinators. Bosch probably did not realise that this ambiguity - doctor or vaccinator - would make the graduates' position unclear. But it seems his strategy worked, as evident from the letter Governor-General J.J. Rochussen sent to Minister of Colonies J.C. Baud, in which he also combined the proposal for the doctors' training and an earlier proposal to improve the cowpox vaccination and pointed out that a joint course would be cheaper than the separate training of doctors and vaccinators. ${ }^{11}$ This illuminates the risk of Bosch's strategy. Rochussen amalgamated the two proposals. His resolution of January 1849 contained the provision that 30 young men could be trained free of charge 'for the job of native doctor and vaccinator'. ${ }^{12}$ In the Colonial Report for 1849, there was no mention of the subsidiary job of vaccinator, but according to the government's resolution of 19 June 1852, the graduates must be prepared to be posted as vaccinator and to provide medical assistance to the general public. ${ }^{13}$ Most sources agree they would be given a dual function.

At the end of 1852, two months before the first cohort was expected to finish the course, there were discussions about their rights, duties and social position (Lauw 1987:92). In a letter to Governor-General A.J. Duymaer van Twist, Bosch rejected making the graduates equivalent to vaccinators; they had followed a sound training 'to be able to practise as a doctor among their people'. ${ }^{14}$ He would like the title 'demang dokter' to be given to them (Lauw 1987:94); demang was the title of a district chief. ${ }^{15}$ The government asked several residents for advice. ${ }^{16}$ They felt that demang was too high and advised not awarding the graduates any higher position than 'mantri cacar', vaccinator (Lauw 1987:92, 94). The

\footnotetext{
1 Letter from GG 26-12-1847 no. 722/2, in: NA, Koloniën, 1814-49, 2.10.01, inv. no. 1849, Vb. 7-4$1848 \mathrm{~N} 2 / 205$. In an earlier letter from 2-11-1846 no. 618/57, the GG proposed to train vaccinators at the three large military hospitals on Java as a trial. This letter had not been answered by the end of 1847 . 12 GB 2-1-1849 no. 22, cited and repeated in GB 19-6-1852 no. 5, Büblad 238.

13 GB 19-6-1852 no. 5, Bijblad 238.

14 Letter from head of the Medical Service to GG 30-11-1852, Lauw 1987:92.

15 Van den Berg (1887:2-3) gives this sequence of native official titles: bupati, patih, jaksa, wedono, demang, mantri.

16 Lauw 1987:94. Probably, this refers to a general request for advice in November 1852 about the training and the future graduates with questions about their title of address and the fees for their treatments.
} 
residents of Pasuruan recommended paying the graduates the same salary as a vaccinator on Java, 40 guilders per month, but grant them their own title - dokter djawa - and permission to carry the payung. ${ }^{17}$ The payung, a parasol, was the highest status symbol in the colonial society on Java and Madura in the eyes of both the native dignitaries and the European administrators. Bosch did not like these recommendations. In March 1853 he informed the governor-general that mantri cacar were 'the lowest Javanese (some were coolies), who did not know anything more than the simplest instructions for vaccination'. ${ }^{18}$ Bosch feared that low social esteem would have a negative effect on applications from students from reputable Javanese families. ${ }^{19}$

Bosch's letter irritated the Council of the Indies. In the articles of association it was clearly specified that the graduates would have to be able to provide medical assistance, but that their job as vaccinator would be more prominent. Therefore, the Council advised granting the graduates the title and the privileges of a vaccinator, mantri cacar, and to put them to work as such. ${ }^{20}$ The Council considered the title dokter djawa too elevated: 'The more the student is raised above his own station, to which his birth in the indigenous community consigns him, the less acceptance he will find in the community; the more envy he will engender in the higher and more privileged classes of society' (Lauw 1987:95). The Council distrusted Bosch and thought that he was aiming 'by means of these native doctors, to spread light and science [...], i.e., to reform the indigenous community through them in agreement with his own peculiar insights' ${ }^{21}$ This reply shows that Bosch had a progressive image. The Council of the Indies clearly did not value scientifically trained doctors; better trained vaccinators were sufficient.

Governor-General Duymaer van Twist ignored these recommendations and instead stood squarely behind Bosch: 'I cannot agree [with the Council's supposition] that the head of the Medical Service must have failed to appreciate the intentions of the specified resolution [the articles

17 Letter from the resident of Pasuruan to GG 26-12-1852 no. 2681, Lauw 1987:94.

18 Letter from head of the Medical Service to GG 12-3-1853, Lauw 1987:92.

19 Lauw 1987:92. Bosch was inconsistent here: in his proposal to establish a school for native doctors, he had insisted that the graduates be granted the right to carry the same payung as a mantri. Lauw 1987:37.

2o Letter 5-4-1853, Lauw 1987:93.

${ }_{21} \quad$ Lauw 1987:95; the passage in italics was underlined by Lauw. 
of association] ${ }^{\prime}{ }^{22}$ In his decree of June 1853, the governor-general formulated the aim of the training more specifically than before to put an end to all the discussion: native young men are given the opportunity 'to qualify for the position of native doctor and vaccinator, and that in this definition [...] first the position of native doctor is given, followed by that of vaccinator' (Lauw 1987:96-7). He also felt that the title mantri cacar would not lead in the population's view to 'increasing the influence of and trust in doctors, without which they cannot prove their worth' (Lauw 1987:96-7). A new training course deserved a new title: 'dokter djawa'(Lauw 1987:96-7). Despite his criticism of the government's policy and the strong tone he often took in his letters - and probably not just there - Bosch was again supported by the highest authority in the colony. In the Netherlands they did not agree: 'Why arouse envy of a title, by giving them this odd name dokter djawa'. ${ }^{23}$

The clear formulation of the government's resolution of June 1853 still did not put an end to the confusion. The graduates' diploma in 1855 stated that they were competent to 'fill the post of vaccinator and native doctor successfully' (Lauw 1987:65). The order was reversed here. Strategy or inconsistency? A few years later, in 1859, the diploma stated that the graduate was competent 'to practise medicine' (Lauw 1987:66); now vaccinator was not mentioned at all. But the argument for the graduates was not yet won, and their position remained vague.

\section{PAYUNG}

In one sense Governor-General Duymaer van Twist followed neither Bosch's advice nor that of the resident of Pasuruan, namely the right to carry a payung. In 1824 the Indies government had classified the titles, ranks and status symbols of the native civil servants in minute detail (Ind. Stb. 1824 no. 13). It had specified which civil servants were entitled to appear in public with a payung, a pike, a mat, a betel-nut set, and an entourage. Their rank could be read from the colours and stripes or circles on the payung (Onderscheidingen 1919:89-90). Three groups in the colonial society on Java carried the payung: first of all, the native administrators

\footnotetext{
$22 \quad$ Citation from GB 5-6-1853 no. 10, Lauw 1987:96-7.

23 Report of the committee charged with examining the report of the management and condition of the East-Indies possessions for 1854, presented in the meeting of 21-7-1857, Handelingen TK 1856-57, part 2:1243.
} 
or heads, such as regents, assistant-regents and district heads, and also the Chinese heads (lieutenant, captain). ${ }^{24}$ The second group consisted of lower native civil servants, the mantri. Apparently the vaccinators, the mantri cacar, had this right as we can deduce from the resident of Pasuruan's advice. The third group was formed of the highest Dutch administrators on Java, the residents and the assistant-residents. For this group, the right was repealed in 1904 by Governor-General J.B. van Heutsz. ${ }^{25}$

There is only one source that reports a European physician with a payung, namely that of Victor Ido (1966:13), pseudonym for Hans van de Wall (1869-1948), who recalls:

Yes, I see the doctor visiting us at home in the 1890s in a long lustre coat with white trousers and a white or black vest. He stepped out of his smart, gleaming coach drawn by one large horse and a runner standing on the running board, armed with a flyswatter for the horse and a payung. This payung served as a parasol or umbrella for 'toewan doctor' [the esteemed doctor] when getting in and out of the carriage, but it was also a sort of attribute of his station. At that time, a European, academically trained physician had an air of sanctity about them for the natives. As far as I can remember, they held a payung only over the head of the 'toewan doctor', aside from the highest official authorities, especially en route to and from his patients. This was in the time of chamomile tea, leeches, mustard pastes and the Holloway salve.

This may have been an individual initiative by a vain family doctor, but it is also possible that Victor Ido gave his vivid imagination free rein, as he often did (Buitenweg 1966:5). Whatever the conclusion, the anecdote illustrates that the payung was the ultimate status symbol in the colonial society. It remains a mystery why Duymaer van Twist refused to grant this to the dokter djawa. While on the one hand he was against the lowly title of mantri cacar, on the other he refused to give them the symbol which would have garnered them respect in the indigenous society. The former teacher at the school for native doctors, J. Alken, ${ }^{26}$ described with a dramatic flair what the lack of a payung meant for the dokter djawa:

\footnotetext{
${ }^{24}$ In the Principalities the Chinese heads carried a payung with a gold or gilded rim; in the other residencies the payung was black painted with red, Ko 1917:513-4.

${ }_{25}$ So-called hormat circular of 3-11-1904, no. 4377, Bijblad 6496.

${ }_{26}$ He was a teacher from 1860 till 1863.
} 
Once the course is completed, they are sent back to their villages to serve there as vaccinator or tukang cacar. They do not have a symbol of distinction, namely a payung and the retinue associated with that insignia, so they are on the same level as the kampong inhabitant. Their peers or kindred rise to the position of mantri or wedono or even higher posts, with all the pomp associated with that position, and with better pay, while throughout their lives they are stuck in one meagre job. When they move to the kampong, they are not received with a gamelan concert like the others are, because they are not owed any tribute, they have no rank in the indigenous society, as they do not carry a payung and have no claim to a retinue. (Alken 1867a)

\section{THE COURSE}

The School ter Opleiding van Inlandsche Geneeskundigen started on 1 January 1851 (Borgers 1941:11). The building in which the students were given their practical training lay on the grounds of the military hospital in Jakarta. At the time of its foundation, G. Wassink was the director of the hospital; he would later succeed Bosch as head of the Medical Service.

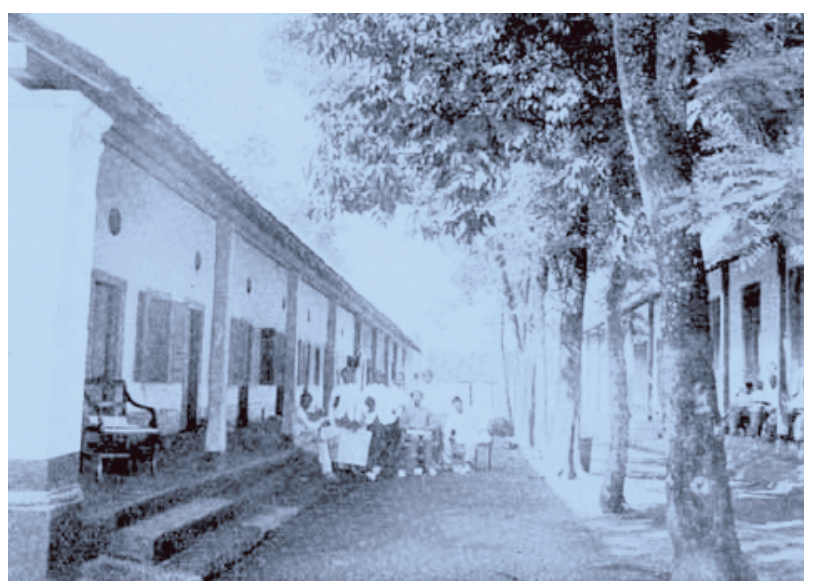

The dokter djawa school around 1896 (De Waart 1926a:12) 


\section{CURRICULUM}

The training course lasted two years. In the first year the curriculum covered physics, chemistry, geology, botany and zoology (principles), human anatomy and physiology, and autopsy studies. Second year studies included surgery and operations done on cadavers; pathology, pathological anatomy and therapy; vaccine theory and skin diseases; materia medica, the most important medicines; and practical training in the clinic. ${ }^{27}$ Clearly this was a wide range of topics, and much more than needed for a vaccinator. The first director of the school, health officer P. Bleeker, was critical of the colonial administration, just like Bosch, and a man with a great scientific curiosity; he developed into a world-famous ichthyologist. Very early on, he wanted to give the course a more scientific character: 'However little educated and prepared, the vast majority of students seemed to have an especially favourable aptitude, which led me to decide quite soon to widen the basis of the training, to extend the teaching to include all of medicine' (Bleeker 1877:34). We don't know which changes in the curriculum this led to, but the first director - naturally after approval by the Head of the Medical Service Bosch - clearly wanted to train the students to be doctors and not just vaccinators. There was no subject in the curriculum devoted to working with the population; most of the teachers had hardly any experience with native patients. The materia medica included indigenous medicinal herbs, though. Starting in 1850 the military hospital established a botanical garden to support these lessons. ${ }^{28}$

\section{STUDENTS}

The articles of association specified that 30 Javanese youths could be admitted to the school, preferably ones coming from respectable families. ${ }^{29}$ Probably this referred to the priyayi, ${ }^{30}$ the Javanese elite from which the native civil servants were recruited. F.D. Cochius, commander of the Indies Army, also assumed this in his response to the original school

\footnotetext{
${ }_{27}$ Wassink 1859a:233. Obstetrics was on the curriculum but was not taught. Borgers 1941:119 listed 16 subjects; Lauw 1987:60 described a variant of the curriculum with 16 subjects, including mechanics, teratology, geography, mathematics up to basic algebra, and geometry.

28 Filet 1855:v; A.R. Schouten 1926:126.

$29 \quad$ GB 2-1-1849 no. 22, Lauw 1987:39.

3o By respectable families around 1850, the elite is meant, Fasseur 2003:79, 82.
} 
proposal: he considered it reasonable to grant the students an allowance during their training, as few natives would be prepared to be away from home for an extended period at their own expense. He doubted whether the proposed 15 guilders per month would be sufficient to attract natives with any refinement, who would be required if the programme was going to have a successful outcome. ${ }^{31}$ In 1853 Bosch reported to the governor-general: 'The name of the school already has such a favourable reputation among the natives that even without having seen it, the aristocracy sends its sons to the institution, in this year and last year, including the regent of Ciamis's son, who is supported by his own means'. ${ }^{32}$ The father's wish was the decisive stimulus because in the same year the final examination was set for the first time, and of the 11 graduates, only one was called mas, the lowest indigenous title. ${ }^{33}$ Later there were more. Among the 81 graduates in the initial phase, 1853-1865, we encounter the title mas 15 times, raden 13 times, si 6 times, ${ }^{34}$ bagindo once and radja once (Lauw 1987:appendix V). In total, 36 (44\%) young men belonged to the priyayi.

A precondition for admission was the ability to read and write in Malay and preferably in Javanese. ${ }^{35}$ This was a tough requirement in those days because hardly any education was provided for natives. In 1847 there were only 34 native students at the Dutch primary schools in the whole of Java. ${ }^{36}$ Many Javanese did send their sons from their sixth to their twelfth year to Islamic religious schools (pesantrèn), where reciting the Koran - in Arabic - was done and Islamic dogma and ethics were studied. ${ }^{37}$ But in these schools, in the first half of the nineteenth century, Arabic was rarely taught (Ricklefs 2007:49); probably, therefore, the teaching was not based on writing. In addition, the number of pesantrèn increased only after 1850 as part of the reform of Islam in the

\footnotetext{
${ }_{31}$ Letter to GG 29-11-1847 no. 10, in: NA, Koloniën, 1814-49, 2.10.01, inv. no. 1849, Vb. 7-4-1848 N 2/205.

32 Letter from Bosch to GG 11-4-1853 no. 322, Archief Schoute Batavia; Ciamis lies in the residency of Cirebon.

33 Letter from G. Wassink [then director of the military hospital and thus probably present during the exams] to head of the Medical Service, W. Bosch, 5-4-1853 no. 96; Archief Schoute Batavia.

34 This was a title on Sumatra in contrast to Java, where it was a normal means of address used by the common man.

35 GB 2-1-1849 no. 22, Borgers 1941:115; Lauw 1987:39.

$3^{6} \quad$ KV 1849:107; Kroeskamp 1974:27 calculates 34 in 1849; Brugmans 1938:139 arrives at 37 students.

$37 \quad$ Kroeskamp 1974:333-4; Brugmans 1961:153.
} 
archipelago in those days (Ricklefs 2007:157). In sum, it was not easy for Javanese and Sundanese youths to meet the entrance requirements; in practice, not everyone did.

All that is known about the recruitment of students is that the residents had to give the head of the Medical Service the names of potential candidates each year on January 1, so the head could make a choice. ${ }^{38}$ This was in all respects new: the government had never established a training programme for natives before; a Western boarding school was just as novel as the position of dokter djawa. For the population the difference between a dokter djawa and a vaccinator was not always clear and that would not have encouraged applications. The residents would probably have discussed the applications with the regents. ${ }^{39}$ It is likely that the candidates registered because the regent asked them to: the adat required obedience by the lower-ranking person towards the higherranking person. We do not know for certain what the motives were of the students or of their parents to choose this training course, but there are indications from early on that the native elite thought that the graduates would enter government service. ${ }^{40}$ This was not formally true. The fact that they could not carry a payung probably influenced the applications, as Bosch feared (Lauw 1987:92).

Because the graduates in principle would work in the region they came from, the applications would ideally be equally distributed over all the different residencies. ${ }^{41}$ The first cohort came from Java, which explains the origin of the title dokter djawa, literally Javanese doctor. Not all the inhabitants of Java were Javanese; there were also Sundanese who did not always sympathise with the Javanese, ${ }^{42}$ perhaps they were unhappy with the title of dokter djawa. In 1854 the first two students entered

\footnotetext{
$3^{8} \quad$ GB 2-1-1849 no. 22, art. 3, Borgers 1941:116; GB 19-6-1852 no. 5, Bïblad 238.

39 The residents had agreed that each regency would delegate one student for the school in surveying in Cirebon, Algemeen verslag onderwijs 1855:188-9. Munnick 1912:137-8 describes how he unsuccessfully exerted pressure on the sultans of Tidore and Ternate to delegate a student for the teacher training school in Tondano. It is not unlikely that the recruitment for the dokter djawa school went through a similar process.

$4^{\circ} \quad$ In the Priangan the dokter djawa complained that native heads and well-to-do natives did not want to pay them, claiming that the government was paying them, AV 1859, Archief Schoute Preanger.

$4^{1} \quad$ Letter from Bosch to GG 11-10-1847 no. 134, in: NA, Koloniën, 1814-49, 2.10.01, inv. no. 1849, Vb. 7-4-1848 N 2/205.

$4^{2} \quad$ After abolition of the Priangan system, the regents in the Priangan wanted to wear official dress, but not the same one as that of the Javanese. 'The Sundanese was simply not fond of the Javanese costume. His sympathy for the Javanese was not that great'. Van den Berge 1998:202-3. In Bandung there were separate chapters for Javanese and Sundanese members of Boedi Oetomo, Ricklefs 2001:208.
} 
the programme from outside Java, namely from the Minahasa. ${ }^{43}$ The low application rate from Java - 8 in 1854 and 3 in 1855 -contributed to the decision to expand recruitment to the Outer Islands (Wassink 1859a:235). Once the first non-Javanese had entered the programme, many more followed. Of the 20 new students in 1856, only 6 came from Java (Wassink 1859a:235). The students from the Outer Islands were not concerned about the payung, as it had no meaning there. They were often better educated than the Javanese. Boys in the Outer Islands may have been taught at government or private schools for indigenous Christians instead of the Islamic schools; there were almost 200 throughout the archipelago in 1852. The vast majority were established in the residencies of Menado and Ambon; there were only 5 on Java (Kroeskamp 1974:40-1).

\section{THE GRADUATES AND THEIR TASKS, $1855^{-1865}$}

In the period 1851-1863, 122 students took the programme: 76 of them graduated while 46 dropped out for various reasons. Of the 76 graduates, 30 were employed as vaccinators, and 11 found work in native clinics. The other graduates - about half - were assigned to the physician charged with the Civil Medical Service in their region. ${ }^{44}$ All graduates, thus also ones with their own practice, were supervised by the European physicians responsible for the Civil Medical Service, primarily health officers, who were required not only to make sure they behaved properly but to promote their further development (Ind. Stb. 1856 no. 70 ).

If the graduates could not find employment immediately as a vaccinator or in a hospital and were not able to support themselves through their own practice, they could obtain a temporary allowance from the government starting from $1856 .{ }^{45}$ The residents had to request it from

\footnotetext{
$43 \quad$ GB 22-4-1854 no. 1; 19-11-1854 no. 1, Bïblad 238.

$44 \quad$ KV 1863:89 listed 7 hospital doctors; Wassink 1859a:236 listed 11 hospital doctors; Lauw 1987:51 listed 76 graduates of whom 1 died, 38 became vaccinators, 11 worked in clinics and 26 provided medical services.

45 GB 19-6-1852 no. 5, Bijblad 238 gives what I feel is an overly rosy image: 'Those choosing this option enjoy from the government a stipend of $f 15$ a month and free accommodation'. This was also stated in $K V$ 1849:94. Later, in, for example, Ind. Stb. 1856 no. 70, a temporary allowance was mentioned.
} 
the government via the head of the Medical Service. ${ }^{46}$ It amounted to 10-15 guilders per month (Lauw 1987:100), a small sum, about what students received during the training for an allowance. It contrasted strongly with the salary of the native teachers, which was set in 1858 at 30 guilders per month with a raise every 5 years to a maximum of 50 guilders (Ind. Stb. 1858 no. 53). A dokter djawa with a family could not possibly live on this amount in accordance with his status; he would have been dependent on his extended family, which would not have increased the popularity of the training. In the first years about half of the graduates ended up in such an unpleasant position.

Bosch's proposal to recruit the students from different residencies with an eye towards their future careers was accepted. ${ }^{47}$ For medical assistance the population was unlikely to turn to someone coming from another region who did not know their language or customs. The colonial reports for the period 1858-1866 stated that almost all the students did indeed return to their region of origin.

There were various positions the dokter djawa could fulfill on the medical market, as given below.

\section{VACCINATOR}

The official name for a vaccinator was mantri cacar; in everyday parlance he was also known as tukang cacar. ${ }^{48}$ The graduates of the dokter djawa school were to be preferred for positions as vaccinator. ${ }^{49}$ Unhappily, just as the first cohort graduated, a new vaccination regulation came into effect that reduced the number of vaccinators employed, leaving hardly any vacancies. In West Java the number was reduced from 78 to $36(\mathrm{KV}$ 1852:72). Many were fired: for example, in the residency of Bogor four of the six vaccinators had to leave. ${ }^{50}$ There was thus little need for new applicants: only 30 of the 76 graduates could find work as a vaccinator.

The training of normal vaccinators was focussed on giving injections and learning to distinguish the features of the vaccine; theory was not taught. It was offered in the hospitals in the three large towns on Java.

\footnotetext{
${ }_{46}^{6} \quad$ Resolution 11-5-1856 no. 3, Ind. Stb. 1856 no. 70.

$47 \quad$ GB 19-6-1852 no. 5, Bïblad 238.

$4^{8} \quad$ Van der Burg 1887:342; confirmed by Professor emeritus A. Loedin in an interview on 8-2-2008.

49 Resolution of 2-1-1849 no. 26, Büblad 43.

$5^{\circ} \quad$ Resolution of 23-12-1852 no. 946, Archief Schoute Buitenzorg.
} 
A vaccinator was a civil servant and had since 1824 the right to carry the payung (Lauw 1987:102). There was a wide range in the salaries of vaccinators: in the Priangan they received a raise in 1854 of 3 guilders to 21 guilders per month, ${ }^{51}$ while their colleagues in Pasuruan received 40 guilders per month. ${ }^{52}$ This was almost twice as much and against the rules, which prescribed a maximum salary of 25 guilders. ${ }^{53}$

It is not clear whether the graduates of the dokter djawa school who found positions as vaccinators enjoyed the same salary and status as the ordinary vaccinators. They may have been paid less because it was assumed that they would set up their own medical practice in addition to giving vaccinations. This appeared not to happen in practice. In 1859 Head of the Medical Service Wassink wrote that the first dokter djawa worked almost exclusively as vaccinators: 'Their activities are of such a nature that it is hard to imagine them running a medical or surgical practice' (Wassink 1859a:236).

\section{HOSPITAL DOCTOR}

If a dokter djawa worked in an institution, it was mostly a small clinic for natives located a few kilometres away from the place where the European physician was based. Formally speaking, the health care provided in the clinic was one of the European doctor's tasks, but he was rarely seen there because of the distance.

The dokter djawa could be placed in the clinic, located 2.5 paal [almost $4 \mathrm{~km}$ ] from the main base and accommodation of the health officer charged with the treatment of patients there. In many serious cases the dokter djawa could provide assistance while waiting for the arrival of the physician, which probably meant the patient could be saved, whereas before it had happened that the disease carried off the patient due to a lack of timely assistance. ${ }^{54}$

\footnotetext{
$5^{1} \quad$ Archief Schoute Preanger 1854.

$5^{2} \quad$ Archief Schoute Pasoeroean.

53 Extract uit Register der besluiten van $G G$ to head of the Medical Service 24-2-1852 no. 23, Winkler and Noordhoek Hegt 1906:appendix Va, xi.

54 Archief Schoute Banjoemas 1860.
} 
This was the case in a leper hospital in Krawang (Jakarta), ${ }^{55}$ in institutions for prostitutes infected with syphilis in Kudus (Semarang), Madiun ${ }^{56}$ and Cianjur (Priangan), ${ }^{57}$ and in general hospitals for natives in Malang (Pasuruan), ${ }^{58}$ Bandung ${ }^{59}$ and Sumedang (Priangan) ${ }^{60}$. The dokter djawa in the clinics earned 20 or 25 guilders per month. ${ }^{61}$ Apparently, the government also assumed that these dokter djawa would run their own practice on the side, which probably - as with their vaccinator colleagues - was hardly possible. In the hospital the dokter djawa was assisted by a mandur, an orderly, a servant, or a woman for the daily nursing tasks. ${ }^{62}$ At that time in the Indies there was no training course for nurses, and this job was done by laypeople. The assistants' salaries ranged from $f 8$ for a man$d u r, f 6$ for an orderly ${ }^{63}$ to $f 10$ for both female and male servants in the native hospital in Malang. ${ }^{64}$ Not only is the generous salary striking in Malang, also men and women earned the same amount. In the syphilis hospital in Bogor, the orderly even earned 20 guilders per month, only 5 guilders less than the dokter djawa there. There was praise for the dokter djawa's enthusiasm, ${ }^{65}$ but clearly little money.

Among the medical institutions, the facilities located near medicinal springs were special. In 1853 it was decided to build a spa at the spring at Tjibeokh (Banten) for the spa visitors and to appoint two dokter djawa to study the working of the medicinal springs; they must have come from the first cohort of graduates. When the head of the Medical Service, G. Wassink, visited the spring in 1854, he ascertained that the dokter djawa were -neither making any precise observations nor keeping records, which meant the effect of the springs was not clear. Nevertheless, in 1857 a second clinic was built beside a spring, and a third was added later, also in the residency of Banten. A dokter djawa was employed at each one. The government paid for the patients' food (Schoute 1936:339-40), which could explain the flood of patients.

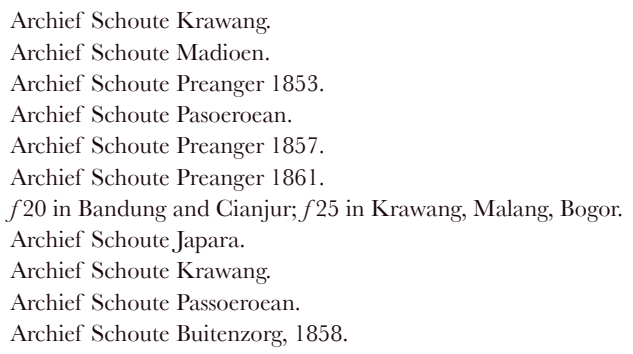


Elsewhere as well, the government invested in medicinal springs. Each year a sum of $f 4000$ was made available for the treatment of sick natives at the springs at Cipanas (Priangan). ${ }^{66}$ It is not clear whether this sum was meant to pay only for the food or also for the appointment of a dokter djawa.

\section{PRIVATE PRACTICE}

Right from the start the government assumed - partly or entirely out of self-interest - that the graduates would obtain sufficient income from their private practice, and thus Bosch's proposal that the government should pay them a fixed salary was considered excessive (Lauw 1987:38). It is not known how well the dokter djawa succeeded in the beginning in establishing their own practices. In combination with providing vaccinations and working in hospitals, it was definitely not possible. According to P. Bleeker, the dokter djawa were opposed by the European doctors when they tried to set up their own practice, and they were subordinate to them: ' $[\mathrm{T}]$ hey were in general rejected and opposed, sometimes from disdain, sometimes from professional jealousy' (Bleeker 1877:36). This attitude described by Bleeker contrasted strongly with the official instructions to Europeans to encourage their development.

The government considered implementing a fixed tariff for the services of the dokter djawa. In November 1852 advice on this was requested from various residents. ${ }^{67}$ The residents of Tegal, Pekalongan and Banten were in favour; the one from Cirebon was not because it would go against the adat, which ruled that services between natives must be rewarded with gifts. ${ }^{68}$ The adat made it difficult for a dokter djawa to ask patients for payment given his low ranking in the indigenous hierarchy and his young age. A superior, socially higher or older, knew the etiquette, so to ask him for money would be presumptuous. If the dokter djawa was not paid by a superior, he had to believe that compensation would come at a better time. When Bosch was commissioned in March 1853 to prepare a proposal about payments, he advised against introducing fixed tariffs

\footnotetext{
66 Archief Schoute Priangan, 1863.

${ }_{67} \quad$ This happened at the same time the residents of Besuki and Pasuruan were asked for advice about the title to be awarded to the graduates. It is thus possible that all residents were asked in November 1852 for advice about the title, tariff, and so on. Schoute 1936:275-6 dated this request to 1855; this is incorrect, however, as already in 1853 a decision was made on this issue (GB 5-6-1853 no. 10).

68 Letter from resident of Cirebon to GG 5-11-1852, Schoute 1936:275-6.
} 
(Lauw 1987:95), and the Council of the Indies agreed with him (Lauw 1987:96). Ultimately, the government did not introduce a tariff. ${ }^{69} \mathrm{In}$ practice, the payment situation created problems. For example, the dokter djawa in Priangan thought that native heads and affluent natives did not want to pay them because they assumed incorrectly they were civil servants receiving a salary from the government. ${ }^{70}$

\section{OTHERS}

The Civil Medical Service consisted of municipal physicians in the three large towns on Java, of civil physicians in the smaller towns and of health officers elsewhere, alongside their military duties. Often the last group complained that they were not able to provide satisfactory assistance, and equally often the residents complained that the officers did not adequately carry out their civil tasks. The dokter djawa would thus be a welcome addition, more hands at the bedside, as we would say today. In the colonial reports their employment during various epidemics was frequently praised. ${ }^{71}$ For example, G.H. Muller, civil physician in Pekalongan, declared that two of the three dokter djawa-vaccinators present there at the outbreak of an epidemic in 1857 provided good services (Wassink 1859b:513-4). Head of the Medical Service Wassink emphasised his utmost satisfaction in his report for 1856: 'Several dokter djawa were charged during epidemics with providing medical assistance in the different villages. They managed to carry out the assignment in such a manner that it inspired trust in European medicine among the people there' (Wassink 1859a:236). Wassink apparently realised that the dokter djawa could be employed to reduce the resistance against Western medicine among the population; he assigned them the role of intermediaries.

\section{APPRECIATION}

Given the original objective of the training programme - offering Western medical assistance to the population to replace the dukun - it is

\footnotetext{
69 GB 5-6-1853 no. 10, Lauw 1987:97; in 1855 this was announced to the regional administrators on Java and Madura and in 1859 to the administrators in the Outer Islands, Resolutions of 19-5-1855 no. 7 and 13-10-1859 no. 45, Bijblad 789.

$7^{\circ} \quad$ AV 1859, Archief Schoute Preanger.

$7^{1} \quad$ KV 1862:94; KV 1865:94; KV 1870:81.
} 
important to know how much the dokter djawa were appreciated by their patients; there are, however, only European sources for this. Head of the Medical Service Wassink noted in 1863 that thanks to the dokter djawa, the population's faith in European medicine increased ( $K V$ 1863:89). As with his predecessor Bosch, Wassink stood squarely behind the dokter djawa school. He was more positive than some residents who wrote in their reports that the population was not favourably disposed to call on the assistance of the dokter djawa. ${ }^{72}$ The natives had much less resistance to European medicines such as quinine; ${ }^{73}$ its use nearly doubled between 1860 and 1866 (KV 1867-68:133). Some Europeans had great hopes for the dokter djawa school in the future: it was destined 'someday to spread rich blessings over Java'. The students would in time reduce the number of victims of the dukun as much as possible (Weitzel 1860:34-5).

\section{REFORM PROPOSALS IN 1863}

In the middle of the nineteenth century, there was a discussion raging in the Netherlands about the standard medical training and the medical sector, a discussion that would culminate in 1865 in the medical laws of Thorbecke. ${ }^{74}$ Some feared that these laws would only augment the existing shortage of physicians in the Indies. Perhaps that is why L.H. Verwey, a doctor in The Hague with experience in the Indies, ${ }^{75}$ suggested in 1861 founding a medical college for Europeans in Jakarta. He received support from the former director of the dokter djawa school, P. Bleeker. Head of the Medical Service Wassink felt the proposal was premature (De Waart 1926a:4); he seized on Verwey's idea to substitute a more realistic proposal, namely an improvement of the dokter djawa training. ${ }^{76} \mathrm{He}$

\footnotetext{
$7^{2} \quad$ Archief Schoute Bagelen 1856, 1857 and Archief Schoute Buitenzorg 1858.

73 While quinine does come from Peru, it was administered in the Indies by Western-trained physicians. Therefore, I call it a 'Western' medicine.

74 J.R. Thorbecke (1798-1872) was prime minister at that time; he was also the initiator of the revision of the Constitution in 1848.

75 L.H. Verwey has a publication under his name, De acclimatatie van Nederlanders in Indië, en van Indiërs in Nederland (1863) [The acclimatisation of Dutch people in the Indies and of Indies people in the Netherlands], which suggests that he had experience as a doctor in the Indies. Lindeboom 1984 did not mention this, however. Archief Schoute Krawang reported that a Dr. Verwey was appointed as a physician there in 1851 and departed two years later.

$7^{6}$ In a letter dated 5-11-1861 to the GG, Wassink asked for authorisation to make proposals for improvement. He submitted the proposals 18 months later in a letter to GG 30-5-1863 no. 750a, Lauw 1987:50.
} 
described its benefits in detail. Not only would the graduates be able to offer Europeans assistance in places where a European physician would not find a decent living, they - more than European doctors - could persuade the population to trust the Western medicine. Again it is clear that Wassink was considering their role as an intermediary.

The Drs Djawa [...] know how to approach their fellow countrymen in such a way as to quickly win the trust of patients, they appear to support their weakness, but have enough knowledge of people to convince them, with patience and gentleness, to show them the error of their ways, that the European way of treating disease is the best choice and deserves the greatest trust. ${ }^{77}$

The mortality among the natives should decrease, especially during epidemics, which would be beneficial for the government not only in humanitarian but also in material terms. There would be more labourers to work the fields (Schoute 1936:277-8). In 1863 Wassink submitted the following reform proposals:

a. 'increase the number of students from 30 to 50 and extend the twoyear course by another year.

b. employ the dokter djawa exclusively to provide medical assistance in the residencies from which they originate and only assign them elsewhere under exceptional circumstances.

c. grant the dokter djawa a monthly income of $f 30$ with a raise every 5 years to $f 50$.

d. permit them to carry a particular model of payung.

e. place them directly under the command of the regional administrators and subject them to the orders of the head of the Medical Service.

f. give every dokter djawa a well-filled medicine chest, at the country's expense and to benefit the population, and make them responsible for it.' (KV 1864:80)

In his clarification Wassink referred to the multiplying requests for dokter djawa from regional administrators and to the growing number of appli-

77 Letter from Wassink to GG 5-11-1861 no. 1304, Archief Schoute Batavia. 
cations from indigenous youths. The latter appeared to be wishful thinking because so far the maximum number of students had never been reached. Wassink considered it essential to extend the training because two years may have sufficed for good vaccinators but not for doctors. He wanted to use the additional year for lessons in, for example, Dutch.

\section{REACTION TO THE REFORM PROPOSALS}

As usual, advice about this proposal was sought, including from the director of Finances. The latter did not see any need to increase the budget; the government had already done enough to offer the population medical assistance. He did not feel it was necessary to raise the number of students because at that moment there were only 17 students studying the course instead of the maximum of 30 (Lauw 1987:53). The Council of the Indies also felt that the 30 available places would have to be filled first before expansion could be considered. It believed it was possible for the dokter djawa to combine their medical practice with the vaccination service. The Council was against a fixed salary because the population had to get accustomed to paying for medical assistance. In addition, it feared that a fixed income would not stimulate the dokter djawa to work hard. It rejected the payung to prevent alienation between the native doctor and the population. ${ }^{78}$ The final result was that the Council rejected all of Wassink's proposals except the medicine chest.

Governor-General L.A.J.W. Baron Sloet van de Beele sent Wassink's reform proposals, including his recommendations, to Minister of Colonies I.D. Fransen van de Putte. In his accompanying letter, he declared that he did not share the objections of the Finance director nor those of the Council of the Indies. ${ }^{79}$ In turn, the minister requested advice from three Indies experts, namely P. Bleeker, the first director of the dokter djawa school, A. Pruys van der Hoeven, assistant-resident of a region on Sumatra's West Coast, ${ }^{80}$ who was on leave in the Netherlands, and J. van Swieten, retired lieutenant-general, former commander of the East Indies army and former governor of Sumatra's East Coast. ${ }^{81}$

\footnotetext{
$7^{8} \quad$ Recommendation 14-8-1863 no. XCII, Lauw 1987:100-1.

79 Letter 4-10-1863 no. 5, Lauw1987: 54.

8o Almanak Nederlandsch-Indië 1863. He was the son of C. Pruys van der Hoeven, professor of internal medicine in Leiden, also known as the father of hygienists.

81 He would be 'called out' again in 1873 to act as commander in Aceh.
} 
For the revision of the dokter djawa training programme - nothing more than a detail within the entirety of colonial politics - a second round of advice in the Netherlands was apparently considered necessary. Most likely, it was an attempt to refute the negative recommendation of the Council of the Indies. Bleeker supported Wassink's proposals passionately and argued strongly for the introduction of Dutch as the language for teaching. ${ }^{82}$ Pruys van der Hoeven advocated for appointing academically-trained European physicians and paying them good salaries, not transferring them often and supporting them with vaccinators, native doctors and midwives. To provide candidates for the latter two positions, each large town on Sumatra would have to have a training institute like the one in Jakarta. Few Sumatrans wanted to go to the school in Jakarta, and when they returned from there, they were ignored by the general population, or took an arrogant tone towards the village heads. He also recommended allowing the dukun to take the training course. He hoped by doing so to add Western science to the local medical knowledge that he felt had great value. ${ }^{83}$ This was an unusual and original recommendation, because he - contrary to most of his compatriots - valued indigenous medicine. In his memorandum, Pruys van der Hoeven stated that he considered good care for the population as a means to encourage their reliance on Dutch authority: 'The writer can confidently predict that where medical supervision works well, a sufficient number of bayonets can be decommissioned, and the savings will amply cover the payment of the medical civil servants'. ${ }^{84}$ Pruys' view of medicine as a tool of empire was quite unusual in those days.

Clearly, Van Swieten had read Pruys van der Hoeven's memorandum; as civil servants active in Sumatra, they probably knew each other. Van Swieten agreed with Pruys van der Hoeven that more medical care was required in the Indies, but he felt academics were too expensive. Therefore, he advised increasing the number of native doctors:

We must not look down on the potential services they could offer, because it is not a great stretch of the imagination to suggest that they could

\footnotetext{
82 Letter 3-2-1864 no. 20, Lauw 1987:54.

83 Memorandum medical civil servants for Sumatra 16-11-1863, in: NA, Koloniën, 1850-1900, 2.10.02, inv. no. 1433, Vb. 27-1-1864 no. 18.

84 Memorandum medical civil servants for Sumatra 16-11-1863, in: NA, Koloniën, 1850-1900, 2.10.02, inv. no. 1433, Vb. 27-1-1864 no. 18.
} 
meet the expectations placed on them and could be acceptable doctors for their fellow countrymen, given the population's simple lifestyle and the uncomplicated disease forms that occur among them and helped by advice from their supervisors, the European physicians. ${ }^{85}$

For Van Swieten the following was as important as for Pruys van der Hoeven: 'the more we civilise the natives in our way of life, the more assured will be the peace and the feeling of sympathy for our authority'. ${ }^{86}$ In other words, both of them assigned the dokter djawa a role as intermediary.

\section{IMPROVEMENTS IMPLEMENTED}

After these three recommendations, Minister I.D. Fransen van de Putte adopted Wassink's proposals with the exception of the right to carry the payung (Ind. Stb. 1864 no. 184; KV 1864:80). L'histoire se repète! It remains noteworthy that attracting upper-class students was still considered important as they could exercise a favourable civilising influence on the population, while at the same time refusing to grant the graduates that status symbol of the elite, the payung. Ultimately, the graduates had a right to a salary, the same one as teachers since 1858 ( $K V$ 1864:80). Furthermore, the implementation of the reform proposals in 1864 clarified the position of the graduates. While the objective in establishing the school was formulated as teaching them to 'become a native doctor and vaccinator', this changed in 1864 to training 'doctors and surgeons' (Lauw 1987:57-8). Unfortunately, this clarity did not last long because as early as 1867 it was specified that dokter djawa were preferred for the position of vaccinator (Ind. Stb. 1867 no. 4). The new head of the Medical Service, A.E. Waszklewicz, ascertained that a dokter djawa as vaccinator could provide medical assistance on the side and thus acquaint the population with Western medicine. ${ }^{87}$ Here again there is a role for the dokter djawa as intermediary.

With the appointment of Waszklewicz as head in 1864, the policy

\footnotetext{
85 Memorandum medical civil servants for Sumatra 16-11-1863, in: NA, Koloniën, 1850-1900, 2.10.02, inv. no. 1433, Vb. 27-1-1864 no. 18.

86 Letter 24-12-1863, in: NA, Koloniën, 1850-1900, 2.10.02, inv. no. 1433, Vb. 27-1-1864 no. 18.

87 Letter from head of Medical Service to member of the Council of the Indies, O. van Rees, 27-21866 no. 101, Lauw 1987:88.
} 
became less ambitious and perhaps more realistic. He wanted to keep Malay as the language of instruction at school; learning Dutch during the training course would take too long in his opinion and was unnecessary. He focussed more on the practice: in the final exam from then on, both theory and practical knowledge would be tested rather than just theory (Lauw 1987:64); and he proposed a mandatory year of practical experience for the new graduates in the municipal hospitals of the large towns. This proposal was presented to the residents of the three large towns, who asked the municipal physicians for their opinion (Lauw 1987:111). Although this seemed a complex procedure for a simple change in policy, it was sensible because the implementation of this change depended on the attitude of the municipal physicians who ruled the municipal hospitals.

Two of the three municipal physicians in Jakarta said they did not have the time to supervise the graduates; given their low salaries, they had to reserve time for a private practice. Both had time enough, however, to express their objections in detail on paper. The third municipal physician hoped for the appointment of more dokter djawa. In sum, the resident concluded that it would be better not to implement the proposal (Lauw 1987:134-5). But in Semarang, the first municipal physician was prepared to do anything to educate the graduates further as he was completely convinced of their usefulness (Lauw 1987:114). In Surabaya, it was a matter of chance whether you were assigned to the first or the second municipal physician for your practical training: the first considered the posting of a dokter djawa a good thing and wanted to have another one himself. The second required you to work hard and did nothing but criticise, often unjustly. ${ }^{88}$

Despite the divided reactions - proponents and opponents were balanced - it was decided in 1868 to introduce the practical year (Lauw 1987:136). Within a year the first municipal physician in Jakarta reported dismissively about his experiences with the trainee doctors: their work 'was always well done previously by an ordinary mandur [supervisor], and it is completely unnecessary to train youths all these years at great expense, to learn by heart many learned words in different languages', ${ }^{89}$ The third physician was also disappointed in his trainee doctor, because

\footnotetext{
88 Lauw 1987:108. The negative judgement of the second municipal physician in Surabaya was so evidently unfair that the resident did not include it in his memorandum.

${ }_{89} \quad$ Letter from Steenstra Toussaint to the resident of Batavia 18-9-1868 no. 92, Lauw 1987:113-4.
} 
the latter had forgotten everything he had been taught during the course. ${ }^{90}$ Such an almost hostile learning environment could not have been optimal for gaining practical experience. The negative attitude of the municipal physicians in Jakarta was known far and wide; the Council of State reported in a letter to King William III in 1874 that European physicians in the Jakarta hospitals did not tolerate dokter djawa as assistants (Lauw 1987:115). But the first municipal physicians in Semarang and Surabaya were full of praise for the graduates and found their presence extremely helpful (Lauw 1987:114).

One of the changes from 1864 concerned awarding a fixed salary to the dokter djawa. The Indies government created a special cost item in the budget for this at the end of 1867. In a dispatch the recently appointed minister of Colonies, J.J. Hasselman, only agreed to this to avoid delay, but he was not convinced of its usefulness or necessity. He felt that by offering free training, the government had already fulfilled its task. With the promise of a fixed income at the end, the number of students would rise, and the wrong type of youths might be attracted. In addition, the graduates could become lazy, and it might prevent them from establishing their own practice. He asked the Indies government for a response. ${ }^{91}$ Since the extensive reorganisation of the local administration in 1867, the Civil Medical Service and thus also the school fell under the Department of Education, Religion and Industry. Its first director, L.J.W. de Waal, took full advantage of the dispatch to evaluate the training. First of all, he requested a response from the head of the Medical Service, A.E. Waszklewicz, ${ }^{92}$ but he did not wait for it before issuing a circular in August 1868 to the regional administrators to ask whether it would be better to stop the dokter djawa training. In addition, the residents were asked for information about the behaviour and the services of the dokter djawa in their region. ${ }^{93}$

\footnotetext{
$9^{\circ} \quad$ Letter from the third municipal physician to the resident of Batavia 4-9-1868 no. 88, Lauw 1987:114.

$9^{1} \quad$ Dispatch 6-12-1867, lett. I, no. 25/1490, Historisch overzicht 1898:19.

$9^{2} \quad$ Recommendation of head of the Medical Service 29-2-1868 no. 388. Historisch overzicht 1898 does not report what Waszklewicz wrote about the dokter djawa course.

93 Circular 4-8-1868 no. 4833, Historisch overzicht 1898:22, 31.
} 
The discussion in the Netherlands about the medical training and the medical sector had come to a conclusion by then. The laws of Thorbecke from 1865 made medical education uniform: only a university course would lead to a medical licence exam. This meant the dissolution of the clinical schools and of the Rijkskweekschool voor Militaire Geneeskundigen in Utrecht where the health officers were educated; they, too, would have to take the medical licence exam from now on. This produced a fierce discussion between proponents such as Prof. F.C. Donders, former student and former teacher at the Rijkskweekschool, and opponents such as J.A. Fles, also a former teacher. Fles (1867a:7) feared that the mandatory medical licence exam would aggravate the already insufficient number of health officers in the Indies. In 1868 there was a shortage of 40, one-quarter of the staff (De Knecht-van Eekelen 1992:409-10). In his second brochure, more a pamphlet, Fles (1867b:6) admitted the following about the Indies: 'BEGAUSE OF THE LACK [of enough health officers], natives were trained to perform as dokter djawa)'. The director of the dokter djawa school, E.P. Tombrink, did not take that lying down. He replied in detail to this phrase, even though it was in parentheses. In an open letter to Fles in the Javabode - one of the largest newspapers in the colony (Termorshuizen 2001:461) - he admitted the shortage of physicians in the Indies, but wrote that it was impossible ever to attract enough European doctors for a population of 20 million. He had great faith in the dokter djawa. The corps of native doctors had 'become a powerful means to strongly promote trust in our European administration, which leaves a lot to be desired in the Outer Islands' (Tombrink 1867a).

The open letter from Tombrink stimulated reactions in the Indies from opponents of the dokter djawa course. Two anonymous writers of a critical article concentrated on the overloaded curriculum and on the director of the school. They also questioned the willingness of the population to call on the dokter djawa. ${ }^{94}$ Obviously, this required a reply from Tombrink (1867b): on the one hand, he appreciated the interest in the school; on the other, he deplored the anonymity of the critics. He denied that the study load was excessive. He was not a proponent of introduc- 
ing Dutch; Malay would over the course of time be just as suitable as any other language for teaching science. The applications from candidates proved that the local population in that area trusted this type of medical assistance, and thus graduates would find sufficient employment there. Several days later the previously mentioned former teacher of the school, J. Alken (1867a), replied with an article in which he stated that the graduates were not eligible to work as doctors due to the poor training. Learning Dutch was absolutely essential because the teachers did not know enough Malay and because the graduates must be able to take refresher courses. He argued for a thorough reform of the programme. In his rejoinder Tombrink (1867c) emphasised the improvements introduced in 1864, which Alken would not have personally experienced as he had retired from the school shortly before, in August 1863. After a last reply from Alken (1867c), the editorial board stopped the exchange in the favabode and concluded that the programme did have a 'great calling' but that so far it had only delivered a few superficial results. ${ }^{95}$ This discussion blew over to the Netherlands; several anonymous articles appeared in the Nederlandsch Tijdschrift voor Geneeskunde. A certain Q (1868:530) had supervised the final exam and heard nothing other than 'lessons learned by heart'. According to him, the dokter djawa were only intended to deceive the public (Q 1868:533). Naturally, the government in The Hague took notice. In May 1869 Minister of Colonies E. de Waal demanded clarification from Governor-General P. Mijer about the recent, unfavourable reports on the dokter djawa school. ${ }^{96}$

THE GRADUATES AND THEIR TASKS, $1865^{-1875}$

The proof of the pudding is in the eating, or did the changes from 1864 have the intended effect on the position of the dokter djawa? The following comparison of posts filled by the 85 dokter djawa graduates in 1868 with those of the 102 graduates in 1873 answers the question (Lauw 1987:8891). Wassink's changes could not yet have affected the group from 1868 as they had only just been implemented. 


\begin{tabular}{|l|c|c|c|c|}
\cline { 2 - 5 } \multicolumn{1}{c|}{} & Total 1868 & Total 1873 & $\begin{array}{c}\text { Proportion } \\
\text { from Java } \\
\text { and Madura } \\
(\mathbf{1 8 7 3})\end{array}$ & $\begin{array}{c}\text { Outer } \\
\text { Islands } \\
(\mathbf{1 8 7 3})\end{array}$ \\
\hline Vaccinator & $38(45 \%)$ & $37(37 \%)$ & 16 & 21 \\
\hline Hospitals/clinics & $7(7.5 \%)$ & $10(10 \%)$ & 9 & 1 \\
\hline Private practice & $19(22.5 \%)$ & $50(50 \%)$ & 31 & 19 \\
\hline Assistant-teacher & - & 3 & 3 & - \\
\hline Spas & - & 2 & 2 & - \\
\hline $\begin{array}{l}\text { Combination }(\text { mostly } \\
\text { vaccinator }+ \text { private } \\
\text { practice })\end{array}$ & $21(25 \%)$ & & 61 & 41 \\
\hline Total & $85(100 \%)$ & $102(100 \%)$ & & \\
\hline
\end{tabular}

Table 4.1. Table of employment of graduates from 1868 and from $1873 .{ }^{97}$

The re-introduction by Waszklewicz in 1867 of the rule that dokter djawa would be preferred for vaccinator posts had no effect; on the contrary, in reality - as evident from table 4.1 - the percentage of dokter djawavaccinator had decreased. In the Outer Islands in 1873, still almost half of the graduates worked as vaccinators. It cannot be deduced from the table that the number of graduates with their own practice had doubled in the 1868-1873 period because in 1873 there was no mention of graduates with a combined position. It does confirm that more dokter djawa had their own practices. Working in a clinic was practically unknown in the Outer Islands as native clinics were first established there at a later date.

One year after his appointment as director of Education, Religion and Industry, De Waal declared he was no longer willing to uphold the rule that graduates should be assigned to their region of origin as far as possible because 'experience has shown [...] that after a 3-year stay in Jakarta, the dokter djawa is not so strongly attached to his birthplace any longer' (Lauw 1987:91). Most likely, De Waal just wanted to be free to assign the graduates anywhere because the number of Javanese students was insufficient to meet the demand from Java. Abandoning this stipula-

97 Lauw 1987:89-91. The figures given in Lauw deviate from those in $K V$ 1870:81, where it was stated that there were 41 dokter djawa-vaccinators in total in 1869. 
tion in 1868 had an effect because in 1873 half of the graduates were working outside their residency of origin (Lauw 1987:91).

\section{VACGINATOR}

The payment of vaccinators improved in the period between 1865 and 1875; they now earned 45 guilders per month. ${ }^{98}$ In addition, they had a right - except in the residency of Jakarta - to three herendienstplichtigen (Ind. Stb. 1867 no. 123 and no. 124), while a dokter djawa had none. A dokter djawa was not immediately appointed a vaccinator; he was first an apprentice-vaccinator ( $K V$ 1866:98). It is alleged that he earned the same in this position as the dokter djawa, namely 30 guilders per month, still much less than the salary of a vaccinator; the government apparently still assumed there would be income from his own practice. The above-mentioned former teacher J. Alken (1867a) knew that the graduates would not have time for their medical tasks because they had their hands full with the vaccination programme. He described complaints in letters from former students that they were only being used as vaccinators.

In this period 37 or 38 dokter djawa worked exclusively as vaccinators. They formed a small minority in the group of 228 vaccinators on Java and Madura and 178 in the Outer Possessions in 1869 (KV 1870:81). In 1874 it was ascertained that there would have to be more uniformity in the payment of vaccinators in the archipelago and that the salary on Java would have to be reduced to $f 30$ per month ( $K V$ 1874:126): the same as the salary of the dokter djawa. Given the difference in training duration, this was unfair. It is depressing to read in an official circular of 1869 that 'an intelligent, physically capable native can be trained quickly, even in one day $[\ldots]$ to substitute temporarily for the position of vaccinator'. ${ }^{99}$ And for a job that was so easy to learn, the government employed dokter djawa with their three years of training.

\footnotetext{
$9^{8} \quad$ Ind. Stb. 1867 no. 125 ; according to Lauw 1987:102, $f 45$ per month with a raise of $f 10$ every 5 years.

99 Circular of Department of Education, Religion and Industry to the regional administrators 24-71869 no. 5919, appendix IV, Winkler and Noordhoek Hegt 1906:viii.
} 


\section{HOSPITAL DOCTOR}

The number of native doctors in native clinics remained constant (10) despite the increase in the number of graduates and the number of institutions. For example, in 1849 there were two leper institutions on Java and Madura, while in 1870 there were four and another ten in the Outer Islands ( $K V$ 1870:78). The increase in the number of native clinics thus did not automatically translate into more employment opportunities for dokter djawa. Probably it was felt that native clinics could manage with a mandur or orderly. Sometimes there was a link between a new clinic and the employment of the native doctors. When the assistant-resident in Krawang in 1868 was allowed to build a small hospital in three districts, he delayed construction of the bamboo buildings until three youths from that region had been trained as dokter djawa. ${ }^{100}$

In the Pegirian institution in Surabaya, $4.5 \mathrm{~km}$ outside the town, beside the marine base and near the brothel camps, about 300 infected women remained under the supervision of the police. They were examined weekly by the first municipal physician and twice a week by a dokter djawa. In Malang 12 sick prostitutes were nursed under the supervision of a dokter djawa; they were accommodated in a civilian clinic on the grounds of the military convalescent home. ${ }^{101}$

\section{PRIVATE PRACTICE}

Two improvements in 1864 likely contributed to the fact that more graduates were capable of running their own practice. The government salary of $f 30$ per month gave them a steady income. Then in that year they were given a filled medicine chest; previously, a dokter djawa had to procure his own instruments by borrowing or obtaining them from the nearest European physician. Purchasing them was impossible given their measly salary; borrowing or obtaining them made the dokter djawa dependent on the European physician, who was not always kindly disposed to them. The contents of the medicine chest give a good impression of the tasks of a native doctor: medicines such as castor oil and quinine, tools to make medicines such as a mortar and a set of scales,

\footnotetext{
100 Archief Schoute Krawang.

101 According to Head of the Medical Service Reiche during his inspection tour of Java in July-August 1871, Archief Schoute Semarang.
} 
and instruments to carry out small interventions such as treating an abscess. ${ }^{102}$ The government paid to keep it refilled (Lauw 1987:105), which produced some problems especially in the large towns. For example, the apothecary in Semarang refused to fill prescriptions from dokter djawa that had not been authorised by the health officer (Lauw 1987:131). In Jakarta they went even further: the Commissie van Geneeskundig Onderzoek en Toevoorzigt [Committee for Medical Research and Supervision $]^{103}$ refused to allow the dokter djawa to write prescriptions and run a private practice independently (Lauw 1987:137). This matched the view of the municipal physicians in Jakarta who were very negative about the dokter djawa. Two of them were members of this Committee. This opposition on the part of some European physicians and apothecaries seems infused with racism. No critical remark was ever heard about the fact that controleurs without any medical training had a medicine chest and could distribute medicines. Perhaps because they were Europeans?

\section{OTHER ASPECTS}

From the start dokter djawa were deployed during epidemics, like the fever epidemic in Semarang in 1866-1869. Fourteen additional native doctors were sent to the afflicted area to visit the kampongs twice a day, administer the medication and search for the sick. This last aspect was necessary because many natives avoided treatment, for example, by hiding away or pretending to be healed. Even in an epidemic, Western physicians and medicines apparently encountered resistance. During the fever epidemic in the residency of Cirebon in the first half of 1867, seven additional dokter djawa were seconded there ( $K V$ 1869:75). The epidemics in Semarang and Cirebon were so severe that all graduates from 1869 were assigned to the afflicted areas ( $K V 1870: 81)$. In both epidemics their activities were greatly appreciated $(K V 1870: 81)$. At the same time an epidemic raged in the residency of Pekalongan, for which no additional native doctors were recruited. However, each of the two dokter djawa working in the residency

\footnotetext{
${ }_{102} K V$ 1875:appendix III, 166-7; according to the Director of the school, L.P. Tombrink (1867a) the medicine chest contained 24 medicines.

103 Schoute 1936:70. This Committee had the following tasks, among others: conducting exams for physicians, midwives and apothecaries; supervising the general state of health in the town; supervising the nursing of civilians in the hospitals and implementing the vaccination programme.
} 
received a bonus of $f 150$ ( $K V$ 1866:98), an enormous sum in comparison to a monthly salary of $f 30$.

In this period dokter djawa were still being employed to nurse indigenous patients at hot springs in the residency of Banten. They not only had to treat the sick, they were also expected to investigate the medical efficacy of the mineral water. ${ }^{104}$ In 1874 Civil Medical Service inspector G. Luchtmans visited the three spas, where a total of two dokter djawa were employed. ${ }^{105}$ They gave him a list of diseases of the patients, and Luchtmans confirmed that the springs did not have any effect on any of them. The dokter djawa had been instructed not to administer medicines in cases of syphilis, probably to prevent an interference of these medicines with the study of the springs' healing properties. Although untreated syphilis was a terrible disease, the patients in Luchtmans's view may have been better off without treatment than with the poor treatment of the dokter djawa in question, whom he labelled 'a medical dunce'. His conclusion was clear:

According to my profound conviction, there is no benefit of the hot springs, without medical treatment. The dokter djawa has been instructed not to carry out real medical treatment, and I don't think he is capable of it anyway, and as a result I consider every guilder spent by the government on the spas to be wasted. Just as I am convinced of the unspecific medical effect of the springs, I am likewise profoundly and morally convinced, though unfortunately I cannot prove it with legitimate witnesses, that the 10 cents paid per day by the government to feed the sufferers ends up in the wrong pocket, that of the dokter djawa. ${ }^{106}$

After this damning report, the government support of the spas was stopped (Schoute 1937:179).

In 1866 for the first time, graduates were appointed as assistantteachers at the school. The best students were chosen. ${ }^{107}$ Both in 1866

\footnotetext{
104 Archief Schoute Bantam 1870; KV 1871:110.

${ }_{105}$ It would have been one of his first assignments, because he was appointed inspector on 5-3-1874, Almanak Nederlandsch-Indië 1875:452.

106 Report about the bathing facilities in the residency of Banten prepared by Inspector G. Luchtmans 10-8-1874, Archief Schoute Bantam.

${ }_{107}$ Art. 13 Regulations of STOVIA from 1899, De Freytag 1899:55.
} 
and in 1867 the assistant-teachers came from Sumatra. ${ }^{108}$ This cannot be a coincidence. Probably the Christians with their good preparatory schooling had a head start over their Islamic colleagues.

At the end of this period, in 1874, in several small areas when the health officer was absent, the local dokter djawa was asked to take over the duties of the Civil Medical Service ( $K V$ 1874:128). A native doctor was now considered sufficiently competent to carry out a task that had previously been reserved for Europeans, if only as deputy.

In this period a dokter djawa was only occasionally employed by a private company, or wanted to be. In 1867, Malim Boengsoe worked for the Billiton Society and was the head of the hospital in Mangar (Tombrink 1867c). In 1874, a dokter djawa asked for permission to work at several spice plantations on Banda. He was not granted this, and so he resigned (KV 1875:127). Apparently, dokter djawa could not have their own practices anywhere in the archipelago while retaining their government salary.

\section{APPRECIATION}

In the 1868 survey, the residents were asked to evaluate the dokter djawa in their residency. This produced a range of results. The residents of the Priangan, Semarang, Yogyakarta and Rembang were very positive. They argued for an increase in their number and improvement of their position (Lauw 1987:107). From three other residencies (Belitung, Kedu and the western part of Kalimantan) there was an urgent demand to send more dokter djawa to help alleviate the desperate shortage of medical assistance there (Lauw 1987:108). Many residents ascertained that the graduates did not have sufficient knowledge to deal with severe cases, but they could help with slight defects and preventive measures; ${ }^{109}$ the latter probably referred to vaccination. Others noted that they could only function under the supervision of a European doctor (Lauw 1987:108). But that did not mean that the dokter djawa were not appreciated. The resident of Besuki was very happy with them: since 1857 there was one employed in his residency and three after 1864, who were so good at dealing with fever and beriberi that 'they were indispensable' (Schoute 1936:334). But Pruys van der Hoeven, at that time assistant-resident of Bengkulu, was critical of the six dokter djawa working in his district in 1866:

108 Respectively, KV 1866:98 and Lauw 1987:124.

109 Lauw 1987:107-8; Lauw specified Timor twice incorrectly, therefore I have left Timor out here. 
They perform little in general, they seem to have adopted manners on Java that are not in favour with the population, put on airs, are lazy and cannot stand up to, or are rather averse to, tiring travel throughout the area. The population does not trust them in turn, and prefers the traditional way of the controleur dispensing medicines for free with friendly advice, than to pay money or chickens for a haughty treatment from the fancily dressed Dr. Djawa. ${ }^{110}$

The residents of Banyumas and Banyuwangi were also disapproving. In their residencies they saw disappointed dokter djawa who were not allowed to carry a payung, did not have labourers (herendienstplichtigen), and thus showed little enthusiasm for their work (Lauw 1987:108). The resident of Krawang could understand why the vacancy in his region was difficult to fill 'given their tiny salary compared to other native civil servants and their very unpleasant working environment'. They needed to be paid more than the mantri cacar who received a higher salary with much less training, two labourers (herendienstplichtigen) and the right to carry a payung. ${ }^{11}$ Some residents remarked in the survey about how little use the population made of their services (Lauw 1987:109). In the residency of Sumatra's West Coast nine dokter djawa were established, but the population preferred 'the traditional medicines and the dukun' (Lauw 1987:107, 110).

Finally, a few positive voices. The resident of the Priangan, C. van der Moore, wrote in his general report for 1867: 'The trust that the population started to place in the dokter djawa in previous years has increased further in the past year. [...] The regents and the most prominent heads let themselves be treated, especially for serious diseases, by the European physicians. ${ }^{112}$ When visiting Padang (Sumatra's West Coast) in 1875, the former teacher J. Alken (1882:3) was delighted to note that one of his students had a thriving practice there and that 14 years after graduating he still remembered the teaching and had developed further. Within the Javanese elite there was interest in the dokter djawa programme; the final exam results were published in Bramartani (Ricklefs 2007:156), the first

\footnotetext{
11 Schoute 1936:334. Pruys van der Hoeven suggested here that the dokter djawa wore a suit adorned with braid, but they were only entitled to this in 1870 .

11 Archief Schoute Krawang 1870.

112 Archief Schoute Preanger 1867.
} 
Javanese newspaper, which was established in $1855 .{ }^{113}$ It is too much to consider this the Javanese elite's appreciation of the work of the native doctors. Perhaps this newspaper, which in general was positive about Western education and Western science (Ricklefs 2007:158-60), only wanted to emphasise that this educational possibility existed. It seems unlikely, however, that the newspaper would have highlighted the training programme if the graduates' work was not appreciated. ${ }^{114}$

The majority of the residents thus produced negative reports, although there were nuances. A minority was satisfied with the dokter djawa, a few considered them a solution for the shortage of medical assistance. The poor labour conditions, including not being allowed to carry the payung, were considered partially responsible for the shortage of native doctors.

\section{THE PAYUNG AGAIN}

In 1867, the official attire for the native teachers was specified in detail with the associated symbols of distinction, including the payung (Lauw 1987:30). Perhaps it was this that prompted two dokter djawa a year later to submit a request to the resident of their region to be allowed to carry the same symbols of distinction as the vaccinators had been permitted since 1824. The resident forwarded it on. After consulting the director of Education, Religion and Industry, L.J.W. de Waal, and the director of the Civil Service, it was turned down by Governor-General P. Mijer, although De Waal had advised giving the dokter djawa who were paid by the government the right to carry the payung. ${ }^{15}$ This recommendation suggests that there were already more dokter djawa in private service than just the two mentioned above. Perhaps De Waal wanted to make government service look more attractive. In any case it seems that he found the dokter djawa were useful for the government.

The rejection by the governor-general is partly based on the argument that a payung was one of the status symbols of native heads and

\footnotetext{
11 Ricklefs 2007:130. The newspaper folded at the end of 1856, to reappear in 1864 as furumartani, and later again under the name Bramartani.

${ }_{14}$ Its pages reflected the expanding horizons and interests of the Javanese upper classes, Ricklefs 2007:159.

${ }_{115}$ Report from 1882, Bïblad 3861.
} 
civil servants, while dokter djawa did not belong to either category. ${ }^{116}$ The salary awarded in 1864 evidently did not mean that they had become civil servants. But De Waal noted in the same year, in a statement about dokter djawa having corvée (herendiensten), that they were civil servants and thus were entitled to the privileges of the native civil servant (Lauw 1987:104). It is embarrassing that discussions were held about whether dokter djawa had corvée while vaccinators were entitled to such labourers, herendienstplichtigen. The governor-general also refused to grant the payung because he felt there was no reason to

increase the dokter djawa's standing among the population by artificial means, when they should be striving to attain that status through useful activities and raising themselves to an honourable position in the indigenous society; that ostentation and celebrations of personal vanity do not match their calling of attending sickbeds, while their training in Jakarta should have taught them that true greatness is not embodied in finery, but in knowledge and diligent devotion to duty, and also that the symbols of authority can only be worn by those who are called to it. ${ }^{117}$

Natives should thus know their place and should definitely not put on airs. This suited the reasoning of a conservative politician such as P. Mijer. Apparently, the government felt that the dokter djawa would have to earn a position through merit. It would not lend a helping hand. However, we know that in the same period the Indies administration was occupied with the status of the dokter djawa. In 1866 it was specified that henceforth an ill student would be treated in the military hospital as a second-class patient and not in the fourth class of primarily servants, native soldiers and quite often forced labourers, taking into account their status and vocation (Lauw 1987:69). Thus, the doctors were required to maintain a certain distance from common folk given their status, but they were not allowed to carry the external symbol of this, the payung. The 'ostentation and celebrations of personal vanity' could strangely enough be combined with positions like teacher and vaccinator. On another note, Director E.P. Tombrink (1867c), who strongly supported the school and its students, was opposed to granting the payung and herendienstplichtigen. He would prefer them to get a higher salary: 'With the spread of general

116 Resolution 26-8-1868 no. 27, Bijblad 2157.

117 Resolution 26-8-1868 no. 27, Bijblad 2157. 
civilisation among the population, to which our dokter djawa undoubtedly do contribute, such privileges will disappear in time on their own. Thus, we would rather see the pioneers of our Western civilisation elevated above all ostentation, working against the common man.'

\section{DRAWING UP THE BALANCE}

In 1873 the balance was drawn up: since the foundation of the school 299 students had been admitted, 163 from Java and Madura, and 136 from the Outer Islands. Of these, 12 had died, 23 dropped out because of illness or at their own request, and 72 were expelled for misconduct; 43 were still at the school (Lauw 1987:84). We note an enormous premature loss: 107 of the 256 students $(42 \%)$. In addition, the maximum capacity of the course - first 30 and then 50 from 1864- was not always reached because the total number of students would then have been 345. ${ }^{118}$ Those who dropped out at their own request did so most likely because of poor prospects or because they had found better employment in the meantime. Waszklewicz had hoped that the fixed income introduced in 1864 would stop graduates from looking for other work (Lauw 1987:101). It did not lead to a decrease in the drop-out rate, however. There were also students who left for other reasons. One of them explained it thus:

Sir will recall that I submitted my resignation from the school several days ago. I didn't do it because I consider myself too stupid, I have always learned well and understood the lessons, sir can ask teacher Taslim about this. I did not want to leave because of misconduct, sir never had to punish me, and can enquire of the supervisor whether he ever had any complaints about me. Now that sir is giving me the chance to express myself freely, I would like to tell you why I am leaving. It was because, once I have graduated as a dokter djawa, I would still be called stupid. That is the reason why I don't want to stay here three years more. ${ }^{119}$

\footnotetext{
118 For 1851-64 the maximum was 30, and the course lasted 2 years; thus at most $61 / 2 \times 30=195$ students could have been admitted; for 1864-73 the maximum was 50, and the course lasted 3 years; at most $1 / 3 \times 9 \times 50=150$.

119 De Waart 1926a:9-10. When this student learned about the improvements in the course for 1875, he decided to stay.
} 
If we take a look at the 149 young men awarded a diploma between 1851 and 1873, we arrive at an average of just seven graduates per year. Of these 149 graduates, 20 had already died, 16 had left the service because of illness or at their own request, and 11 had been fired because of incompetency (Lauw 1987:91). There were thus 102 in government service $(68 \%)$. The loss among the graduates is in some cases unavoidable, but it can be partly attributed to the poor working conditions. Those who resigned of their own accord must have had a better alternative in mind such as employment in a private company. Only $40 \%$ of the number of students who started the training were still in government service.

\section{NEW START IN 1875}

Let us return to the request from The Hague in May 1869 for a reply to all the criticism and commotion. Civil servants in Jakarta had since received the replies to the 1868 survey and had probably made the same calculations as given above about the outcome of the programme. Something had to be done, a choice made between closing the school or extensive improvement. The time was ripe for a radical choice at the same moment that several changes in the top personnel took place. Since 1867 the school was supervised by Director for Education, Religion and Industry L.J.W. de Waal. In 1868 a new director was appointed to the school, J.J.W.E. van Riemsdijk. Action could only be undertaken, however, after the departure of Head of the Medical Service A.E. Waszklewicz in April 1870; with his retirement the last of the men present at the foundation departed, the group that heart and soul defended the school and would not tolerate any criticism. After the appointment of the new head, M.Th. Reiche, De Waal, Reiche and Van Riemsdijk regularly discussed the training programme. In December 1872 Reiche was formally requested by the director for Education, Religion and Industry to make recommendations about the dokter djawa course, ${ }^{120}$ and a year later the essential proposals for improvement appeared. ${ }^{121}$ Just like in 1864, they included an increase in the number of students (from 50 to 100) and lengthening of the duration of the course (from

\footnotetext{
120 Letter 21-12-1872 no. 12010, Historisch overzicht 1898:30. The same letter also assigned the task to evaluate closing the midwifery school.

${ }^{121}$ Recommendation 28-6-1873 no. 994, Historisch overzicht 1898:33.
} 
three to five years: two years of general education and three years of medical tuition). Analogously, increasing the number of students was considered unnecessary because the maximum had never been reached. New aspects included the proposals to introduce Dutch as the language of instruction and force the graduates to work in government service for ten years (Lauw 1987:141). The latter proposal was probably meant to reduce the drop-out rate. For the first time, not a word was said about the payung. Probably the rejection in 1868 was still fresh in their memories, or perhaps such an indigenous status symbol did not suit the vision of the new top management of the training programme and its graduates. By choosing Dutch and a considerable extension of the training, they may have wanted to revamp it to make it more Western.

These proposals followed the usual path of progression: from the director of Education, Religion and Industry to Governor-General J. Loudon for advice to the Council of the Indies, and finally to the Crown. ${ }^{122}$ The only modification made along the way was the removal by the Council of the Indies of the obligation to work in government service for ten years. The Crown did indeed ask for advice from the Council of State, which in turn consulted good old Bleeker, who must have been delighted to see his old wish - Dutch as the language of instruction - finally coming true. With a Royal Decree, the proposal was approved (Lauw 1987:140-2). Concurrently, it was decided to close two other medical programmes: the midwifery school and the veterinary school. The authorities were apparently convinced that well trained native doctors could fulfil a useful function in the Civil Medical Service.

FINALLY, THE PAYUNG

Just when it seemed that they would have to forget about the payung forever, the issue was stirred up again by a dokter djawa, Mas Prawiro Atmodjo. In 1882 he submitted a request to the resident of the Priangan to be allowed to carry the payung; the resident forwarded the request to the director of Education, Religion and Industry, W. Stortenbeker, Jr. In his recommendation to the governor-general, Stortenbeker pointed out that the government had prescribed official dress for this group of

122 Respectively: letter from the director of Education, Religion and Industry to GG 2-10-1873 no. 9651 and Indies letter from 5-11-1873 no. 1594a/25, Historisch overzicht 1898:30. 
civil servants in 1870 and that in 1875 the position of dokter djawa had improved enormously. In November 1882 Governor-General F. s'Jacob gave his permission; the payung was granted to the dokter djawa working on Java and Madura in government service. After all, this status symbol was not used on other islands. In his considerations, s'Jacob wrote,

that it is not unimportant for the government to help support the dokter djawa, whose training costs a lot of money and effort, to gain in respect among the population, whereby the trust in their learning and competency cannot but increase; that in addition the granting to the dokter djawa of an official payung deserves recommendation, because it can be expected that it would encourage young men of good families to apply for the gainful employment. ${ }^{123}$

That the training cost a lot of money seems exaggerated given the tiny budget reserved for the programme. The argument that the dokter djawa's standing and expertise would increase in the population's eyes by carrying the payung had been stated several times in the past, for example by Bosch who had hoped to interest young men from good families in the profession by this means. Probably this was the real reason behind the approval. At that time three-quarters of the students came from a low social class. ${ }^{124}$ The government had apparently been convinced in the meantime - partly because of the 1875 reforms - of the usefulness of the dokter djawa in the Civil Medical Service, and greater success could be expected if more students would apply from a better social background. Then the only question remaining is why the government did not grant the payung of its own accord.

\section{BUDGET}

The budget reserved for the training programme has already been mentioned in passing several times. In March 1848 the cabinet decided to stop all new civilian expenses in the Netherlands East Indies. ${ }^{125}$ This

\footnotetext{
123 Resolution GG 3-11-1882 no. 2, Büblad 3861; KV 1883:117.

${ }_{124}$ Jaarlijksch verslag STOVIA 1906:appendix 10; see table 6.2 in this book.

${ }_{125}$ Cabinet resolution 13-3-1848, in: NA, Koloniën, 1814-49, 2.10.01, inv. no. 1845, Vb. 22-3-1848 no. 26.
} 


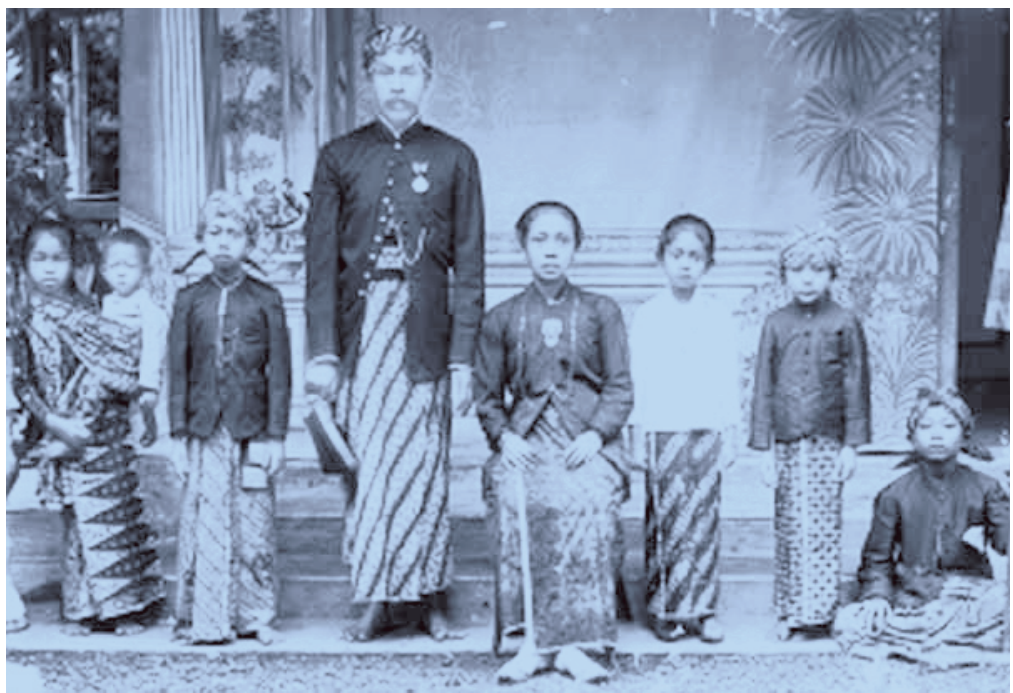

Dokter djawa Samgar in full splendour: payung, bare feet, kain, folded cloth as a headdress, official cap in hand, medal decorations and (golden?) watch chain on the coat. It is a photo from 1920. (Photo collection KITLV 2915)

apparently was not strictly enforced because shortly thereafter it was decided to commit $f 5,400$ per year for the new training of native doctors. ${ }^{126}$ Governor-General Rochussen noted that this was a very small expense in comparison to the great benefit that was expected. ${ }^{127}$ In the same year (1848) a considerably higher sum, f25,000, was reserved for setting up schools for the Javanese population, aiming particularly at the training of civil servants, ${ }^{128}$ likewise, an area of policy that the government had not previously invested in. That there indeed was a restricted budget is apparent from the denial in 1848 of the governor-general's request for an additional amount for the vaccination programme of $f 30,000$ per year, ${ }^{129}$ although this was not a new policy and thus did not formally come under the budget restrictions. In 1850 this request was

\footnotetext{
126 GB 2-1-1849 no. 22, art. 2, Borgers 1941:115.

127 Letter from GG 26-12-1847 no. 722/2, in: NA, Koloniën, 1814-49, 2.10.01, inv. no. 1849, Vb. 7-4-1848 N 2/205.

128 KB 30-9-1848 no. 95, Kroeskamp 1974:299.

129 NA, Koloniën, 1814-49, 2.10.01, inv. no. 1845, Vb. 22-3-1848 no. 26.
} 
granted along with $f 20,000$ to combat syphilis (Schoute 1936:269), also not a new item in the budget.

On the one hand, these are the years of the Batig Slot, which in 1851 alone produced $f 7,879,447$, a huge sum, making it difficult to understand the need for budget restrictions. On the other, the proceeds from the Indies financially supported only the mother country. GovernorGeneral J. van den Bosch had the budget of 1835 declared binding for the future. Only expense items for the government plantations could be increased; other expenditure was frozen at the 1835 level. The budget for a particular year was only set when it was known how much was 'left over' from the previous year, with the result that the Indies budget was not set until halfway through the financial year. Governor-General Duymaer van Twist wanted to end this practice: he wanted the budget to be ready before the start of the financial year. He also wanted to make the budget he prepared for 1852 the standard instead of the one for 1835. The minister of Colonies was not in favour, however, given that the draft budget for 1852 was higher than the one for 1835. He stuck to the principle that items could not be increased without permission from the administration in The Hague (Zwart 1939:89-93). The power of the governor-general over finances was limited. Even over a relatively small expense - in comparison with the Batig Slot - of $f 5,400$ for the dokter djawa school, he could not issue a command. In another sector - irrigation projects - the financial latitude of the governor-general - or his interest - was apparently bigger. In the 1850s, the Brantas irrigation project was only realised through his generous support: ' $[\mathrm{H}]$ e granted the necessary funding, a sum of 24 tons of gold, without consulting the supreme administration [in the Hague]', according to H. de Bruyn, the later director of the Department of Civil Public Works (Van Doorn 1994:138). Against such a sum, the amount for the dokter djawa training pales in comparison.

\section{CONCLUDING REMARKS}

The training programme for native doctors was a novelty: the government had not made itself formally responsible before for the health of the population and invested in it. But it sounds better than it was because for a structural sum of $f 5,400$ per year - and a one-off sum of $f 6,978$ for the construction and furnishing of the school - it was a cheap experi- 
ment. Minister of Colonies J.C. Baud said something very similar when in 1847 he talked about a proposal with 'no major financial obstacle'. For a pittance the government could make a generous gesture towards the liberal opposition in Parliament: one of the motives for establishing the training programme was humanitarian, better health care for the population. The desire to stop 'the devastating evil' of the damned dukun must not cost too much money. As the population of Java grew enormously in the nineteenth century ${ }^{130}$ - despite the assumed poor health of the population - that was not an argument to improve their care.

The experiment was not only cheap, it was also half-hearted. While the government did pay for the training, for a long time it was unclear what to do with the graduates. Or as the first Director P. Bleeker wrote, '[T] he school's success did not generally extend much further than the school itself' (Bleeker 1877:36). At the beginning, the graduates were employed as vaccinators with a lower wage - and poorer labour conditions (no payung, no herendienstplichtigen) - than the normal vaccinators because it was assumed that they would establish their own private practice. At the same time, the government held back important elements for their own practice such as a fixed salary, a medicine chest and the payung. Their position as vaccinators did increase their usefulness for the government, giving them the right to exist, while in their function as dokter djawa, they still had to prove their value. The half-heartedness was expressed in the low payment: first it concerned a temporary subsidy, which was later transformed into a regular payment and even later into a salary and government employment. The labour conditions stood in shrill contrast to those of the native teachers and vaccinators.

The poor labour conditions had various effects. It is not inconceivable that the application rate from Java was so low in comparison with that from the Outer Islands because of the ban on carrying the payung, a status symbol used only on Java. The high drop-out of students can be partly ascribed to this. The poor prospects gave some students a reason to search for another job. A few graduates found work with a private company, where the labour conditions were better. At a certain moment the government realised that it could probably counteract the students leaving by improving the labour conditions, such as awarding a fixed salary and the payung.

130 Many sources reported this, including Ricklefs 2007:252. 
Which position did the newcomers occupy in the medical market? Given the low number of graduates - 102 in 1873 - their influence cannot have ever been great. Among the population there was a general resistance to Western medical assistance and thus against the dokter djawa, but during epidemics they did accept help, and the dokter djawa were useful then. Sometimes they experienced competition from controleurs who were popular with the population because they gave away medicines for free. Some European physicians did sabotage the dokter djawa they were supervising out of professional jealousy; therefore, it was decided in 1864 to place the dokter djawa under the supervision of the local regional administrator instead.

There are various indications that the government wanted to employ the graduates as intermediaries in the medical market to introduce Western medicine to the population. From its establishment, official documents and elsewhere referred to the fact that dokter djawa were more effective than European doctors, given that they would be more likely to win the trust of the population for Western medicine. European doctors usually did not know the vernaculars well enough to communicate. Many spoke Malay more or less, but that was a language of commerce and not the languague of the native population itself. The dokter djawa spoke their languauge and knew their customs certainly if they returned to their region of origin. This benefit was lost when for pragmatic reasons the government abandoned the principle that graduates would work in their region of origin.

All in all, it is a marvel that the school still existed in 1875 and even more that the training programme was being radically improved. It is a wonder that the founder of the school, W. Bosch, who was known to be a critic of the colonial administration, was supported twice at critical junctures by the supreme authority in the colony, the governor-general. And it is also amazing that despite the poor labour conditions and other problems, there were still enough native doctors who wanted to do this work. Their accomplishments showed how useful they could be for the government and how they made the government willing to invest in the training programme. 